\title{
The basicity of mixed oxides and the influence of alkaline metals: the case of transesterification reactions
}

\author{
José M. Fraile,* Nuria García, José A. Mayoral, Elísabet Pires, * Laura Roldán \\ Departamento de Química Orgánica. ICMA. C.S.I.C. - Universidad de Zaragoza and \\ IUCH, Universidad de Zaragoza. Pedro Cerbuna 12, E-50009 Zaragoza (Spain)
}

\begin{abstract}
Several $\mathrm{M}(\mathrm{II}) / \mathrm{M}(\mathrm{III})$ mixed oxides were prepared and tested in two different transesterification reactions, biodiesel production from sunflower oil and methanol, and the more demanding transesterification of methyl palmitate with isobutanol. The presence of residual alkaline ions after crystallization is the main source for the strong basicity in this kind of solids, as it happened with $\mathrm{Mg} / \mathrm{Al}$ mixed oxides. The effect of these alkaline traces is more evident with the most demanding reaction, in which the alkaline-free solids did not show any catalytic activity. These results seem to indicate that the strong basicity in mixed oxides is always connected to the presence of alkaline metals, irrespective from the nature of $\mathrm{M}(\mathrm{II})$ and $\mathrm{M}(\mathrm{III})$.
\end{abstract}

Keywords: Transesterification, hydrotalcite, mixed oxide, basicity, leachable basicity.

Correspondence author: Dr. José M. Fraile

Address: Departamento de Química Orgánica, Facultad de Ciencias, Universidad de Zaragoza, E-50009 Zaragoza (Spain)

Phone: +34976762272

Fax: +34 976762077

e-mail: jmfraile@unizar.es 


\section{Introduction}

The nature of the basic sites in heterogeneous catalysts [1] is still poorly understood and this is probably one of the reasons for the relatively scarce application of solid basic catalysts in organic reactions. $\mathrm{Mg}-\mathrm{Al}$ mixed oxides and analogues with other divalent $(\mathrm{Ca}, \mathrm{Zn})$ and trivalent cations ( $\mathrm{La}, \mathrm{Ga})$, prepared from mixed hydroxides with

hydrotalcite structure of general formula $\left[\mathrm{M}^{2+}{ }_{(1-\mathrm{x})} \mathrm{M}^{3+}{ }_{\mathrm{x}}(\mathrm{OH})_{2}\right]^{\mathrm{x}+}\left(\mathrm{A}^{\mathrm{n}-}\right)_{\mathrm{x} / \mathrm{n}} \cdot \mathrm{yH}_{2} \mathrm{O}$ [2], have been reported as excellent basic catalysts for different organic reactions [3]. In the case of transesterification reactions, such as biodiesel production or analogous model reactions, several mixed oxides have been used as catalysts [4-11]. Solids were prepared by precipitation with sodium [5,7-11] or ammonium [4,11] bases, commercially available hydrotalcite was found active [6] or inactive [7] in different works, and the effect of the composition on activity was also found different in several papers $[4,5,8,9,11]$, conforming a quite puzzling set of results.

In these solids several basic sites have been proposed from calorimetric and spectroscopic measurements [12], that have been identified as $\mathrm{O}^{2-}$ (strong), Mg-O pairs (medium), and $\mathrm{OH}^{-}$(weak) groups. Discrepancies were observed in the number of basic sites determined by TPD/calorimetry of $\mathrm{CO}_{2}[12,13]$ and titration using different Hammett indicators [5] over mixed oxides a priori prepared in the same way. Moreover soluble basicity was detected in several cases $[5,11]$. The term leachable basicity was introduced in a previous paper [14] to reflect the potential homogeneous character of the strong basic sites. As can be seen from those results, the nature and amount of the basic sites are intriguing features of the mixed oxides obtained from hydrotalcite calcination. The discrepancies observed in the basicity determination, even using the same method, may be due to the inconsistency of the method itself, or to the lack of reproducibility in 
the hydrotalcite preparation, leading to solids with very different basic properties and hence difficult to compare from one work to another.

The presence of trace of alkaline metals was proposed as the origin of the strong and leachable basicity in Mg-Al mixed oxides $[14,15]$. The difficulty in reproducing the preparation method and the lack of strong basicity of the thoroughly washed solids make almost impossible the practical application of the $\mathrm{Mg}-\mathrm{Al}$ mixed oxides in reactions requiring strong bases in quite polar reaction media.

Other mixed oxides have been reported as basic catalysts, such as $\mathrm{Zn}-\mathrm{Al}$ and $\mathrm{Mg}-\mathrm{Zn}-\mathrm{Al}$ mixed oxides [9,16-18] or Mg-La mixed oxides [19], and they have been used in transesterification reactions. In this paper we explore the generality of the role of alkaline metals in the basicity of different mixed oxides, by their application in transesterification reactions. 


\section{Experimental}

\subsection{Mg-Zn-Al and Zn-Al catalysts preparation (general procedure)}

$250 \mathrm{ml}$ of an aqueous solution of $\mathrm{Mg}\left(\mathrm{NO}_{3}\right)_{2} \cdot 6 \mathrm{H}_{2} \mathrm{O}, \mathrm{Zn}\left(\mathrm{NO}_{3}\right)_{2} \cdot 6 \mathrm{H}_{2} \mathrm{O}$ and $\mathrm{Al}\left(\mathrm{NO}_{3}\right)_{3} \cdot 9 \mathrm{H}_{2} \mathrm{O}$

of the desired $\mathrm{Mg} / \mathrm{Zn} / \mathrm{Al}$ ratio (total metal concentration $1 \mathrm{M}$ ) were slowly added to 600 $\mathrm{ml}$ of distilled water at $333 \mathrm{~K}$. At the same time a $2.4 \mathrm{M}$ solution of $\mathrm{Na}_{2} \mathrm{CO}_{3}$ and $\mathrm{NaOH}$ $\left(\mathrm{Na}_{2} \mathrm{CO}_{3} / \mathrm{NaOH}=0.06\right)$ was added in order to maintain $\mathrm{pH}$ at the desired value (10 or 7 $\pm 0.2)$. The solids were named with the metals ratio and the precipitation $\mathrm{pH}$ : for example $\mathrm{Mg}_{8} \mathrm{Zn}_{1} \mathrm{Al}_{1}(10)$ is a solid prepared with a $\mathrm{Mg} / \mathrm{Zn} / \mathrm{Al}$ ratio $=8: 1: 1$ at $\mathrm{pH}=10$. When all the metal solution was added, the mixture was kept at $333 \mathrm{~K}$ for two hours. The solid was filtered and washed with distilled water at 333K. Typically as-prepared solids were washed with $500 \mathrm{ml}$ of water, whereas for thoroughly washed solids a volume of 3-4 1 of water was used. Then the solid was dried overnight at $343 \mathrm{~K}$. The catalyst precursor was sieved at a particle size between 160 to $400 \mu \mathrm{m}$ and calcined under $\mathrm{N}_{2}$ flow at $723 \mathrm{~K}$ for $14 \mathrm{~h}$.

\subsection{Preparation of $\mathrm{Zn}_{4} \mathrm{Al}_{1}\left(7-\mathrm{NH}_{4}\right)$}

$200 \mathrm{ml}$ of an aqueous solution of $\mathrm{Zn}\left(\mathrm{NO}_{3}\right)_{2} \cdot 6 \mathrm{H}_{2} \mathrm{O}$ and $\mathrm{Al}\left(\mathrm{NO}_{3}\right)_{3} \cdot 9 \mathrm{H}_{2} \mathrm{O}(\mathrm{Zn} / \mathrm{Al}$ ratio $=4$, total metal concentration $1 \mathrm{M}$ ) was slowly added to $600 \mathrm{ml}$ of distilled water at $333 \mathrm{~K}$. At the same time $40 \mathrm{ml}$ of a $1 \mathrm{M}$ solution of $\mathrm{Na}_{2} \mathrm{CO}_{3}$ was added in order to maintain $\mathrm{pH}$ at $7 \pm 0.2$ and, once consumed, the $\mathrm{pH}$ was maintained by addition of a $1 \mathrm{M}$ solution of $\mathrm{NH}_{4} \mathrm{OH}$.

When all the metal solution was added, the mixture was kept at $333 \mathrm{~K}$ for two hours. The solid was filtered and washed with distilled water at $333 \mathrm{~K}$. Then the solid was dried 
overnight at $343 \mathrm{~K}$. The catalyst precursor was sieved at a particle size between 160 to $400 \mu \mathrm{m}$ and calcined under $\mathrm{N}_{2}$ flow at $723 \mathrm{~K}$ for $14 \mathrm{~h}$.

\section{$2.3 \mathrm{Mg}$-La catalysts preparation (general procedure)}

The catalyst was prepared according to the method described by De Vos and coworkers [20]. A solution of $0.132 \mathrm{~mol}$ of $\mathrm{Na}_{2} \mathrm{CO}_{3}$ in $100 \mathrm{ml}$ of water was slowly added (rate of $1.6 \mathrm{ml} / \mathrm{min})$ to $200 \mathrm{ml}$ of an aqueous solution of $0.09 \mathrm{~mol}$ of $\mathrm{Mg}\left(\mathrm{NO}_{3}\right)_{2} \cdot 6 \mathrm{H}_{2} \mathrm{O}$ and 0.01 mol of $\mathrm{La}\left(\mathrm{NO}_{3}\right)_{3} \cdot 4 \mathrm{H}_{2} \mathrm{O}$. When all the basic solution was added, the mixture was kept at 353K for one hour. The solid was filtered and washed with distilled water. Then the solid was dried overnight at $343 \mathrm{~K}$. The catalyst precursor was sieved at a particle size between 160 to $400 \mu \mathrm{m}$ and calcined under $\mathrm{N}_{2}$ flow at $713 \mathrm{~K}$ or $873 \mathrm{~K}$ for $14 \mathrm{~h}$. $\mathrm{Mg}_{9} \mathrm{La}_{1}\left(\mathrm{NH}_{4}\right)$ was prepared by the same method but the $\mathrm{Na}_{2} \mathrm{CO}_{3}$ solution was substituted by $100 \mathrm{ml}$ of $\mathrm{NH}_{4} \mathrm{OH} 30 \%$.

\subsection{Mg-Al and Mg-Ga catalysts preparation (general procedure)}

An aqueous solution of $\mathrm{Mg}\left(\mathrm{NO}_{3}\right)_{2} \cdot 6 \mathrm{H}_{2} \mathrm{O}$ and $\mathrm{Al}\left(\mathrm{NO}_{3}\right)_{3} \cdot 9 \mathrm{H}_{2} \mathrm{O}$ or $\mathrm{Ga}\left(\mathrm{NO}_{3}\right)_{3} \cdot \mathrm{xH}_{2} \mathrm{O}$ of the

desired $\mathrm{Mg} / \mathrm{M}^{+3}$ ratio (total metal concentration $1 \mathrm{M}$ ) was slowly added to $700 \mathrm{ml}$ of distilled water at $333 \mathrm{~K}$. At the same time a $2.4 \mathrm{M}$ solution of $\mathrm{Na}_{2} \mathrm{CO}_{3}$ and $\mathrm{NaOH}$ $\left(\mathrm{Na}_{2} \mathrm{CO}_{3} / \mathrm{NaOH}=0.06\right)$ was added in order to maintain $\mathrm{pH}$ at the desired value $(10 \pm$ 0.4). When all the metal solution was added, the mixture was kept at $333 \mathrm{~K}$ for two hours. The solid was filtered and washed with distilled water at 333K. Then the solid was dried overnight at $343 \mathrm{~K}$. The catalyst precursor was sieved at a particle size between 160 to $400 \mu \mathrm{m}$ and calcined under $\mathrm{N}_{2}$ flow at $723 \mathrm{~K}$ for $14 \mathrm{~h}$. 


\subsection{Catalyst characterization}

Analyses of metals ( $\mathrm{Mg}, \mathrm{Ga}, \mathrm{La}, \mathrm{Zn}, \mathrm{Al}, \mathrm{Na})$ were carried out by plasma emission spectroscopy on a Thermo Elemental, IRIS Intrepid Radial emission spectrometer.

Step scanned X-ray diffraction patterns of oriented samples were collected at room temperature from $3^{\circ}$ in $2 \theta$ up to $80^{\circ}$, using D-Max Rigaku system with a rotating anode. XPS measurements were carried out on an Axis Ultra DLD (Kratos Tech.) with monochromatizedA1K $\alpha$ source $(1486.6 \mathrm{eV})$ at $15 \mathrm{kV}$ and $10 \mathrm{~mA}$. Samples were evacuated at room temperature.

Surface areas were determined by $\mathrm{N}_{2}$ adsorption (BET) using a MicromeriticsASAP 2020 apparatus. Typically, $0.2 \mathrm{~g}$ of calcined solid was used for measurements. Prior to $\mathrm{N}_{2}$ adsorption, the sample was outgassed for $4 \mathrm{~h}$ at $423 \mathrm{~K}$.

Thermogravimetric analysis (TGA) was performed using a TA Instruments STD 2960 simultaneous TGA-DTA at a rate of $10^{\circ} \mathrm{C} / \mathrm{min}$ under synthetic air atmosphere. TGA data are given as the onset of decomposition curve. In addition, the first derivative of decomposition curve (DTGA) was read.

The quantitative determination of basicity was done by titration with benzoic acid [5, 21]. A suspension of calcined solid $(0.15 \mathrm{~g})$ in a toluene solution of phenolphthalein (2 $\mathrm{ml}, 0.1 \mathrm{mg} / \mathrm{ml}$ ) was stirred for $30 \mathrm{~min}$ and then titrated with a toluene solution of benzoic acid $(0.01 \mathrm{M})$ to determine the total basicity. A sample of calcined solid $(0.5 \mathrm{~g})$ was shaken in water $(50 \mathrm{ml})$ for $1 \mathrm{~h}$ at room temperature, the catalyst was filtered off, a methanol solution of phenolphthalein $(5 \mathrm{ml}, 0.1 \mathrm{mg} / \mathrm{ml})$ was added to the filtrate, which was titrated with a methanol solution of benzoic acid $(0.01 \mathrm{M})$ to determine the leachable basicity. 


\subsection{Transesterification reaction of sunflower oil with methanol}

Transesterification reaction of sunflower oil with methanol was carried out in a round flask under reflux using $2 \mathrm{~g}$ of oil, $3 \mathrm{ml}$ of methanol and catalyst/oil ratio $10 \%(\mathrm{w} / \mathrm{w})$ for 3 h. The catalyst was filtered off and washed with methanol and ether. The crude reaction mixture was analyzed by gas chromatography using eicosane as internal standard. The GC analysis was performed using an HP-5890-II chromatograph equipped with FID detector, an SPB-5 $5^{\mathrm{TM}}$ column: $30 \mathrm{~m} \times 0.25 \mathrm{~mm} \times 0.25 \mu \mathrm{m}$, He as carrier gas 20 psi temperature: $280{ }^{\circ} \mathrm{C}$; detector temperature: $300{ }^{\circ} \mathrm{C}$; oven program: isotherm $205{ }^{\circ} \mathrm{C}(30 \mathrm{~min})$, retention times: eicosane $6.9 \mathrm{~min}$, methyl palmitate $5.7 \mathrm{~min}$, methyl estearate $9.1 \mathrm{~min}$, methyl oleate $9.2 \mathrm{~min}$, methyl linoleate $9.8 \mathrm{~min}$

\subsection{Transesterification reaction of methyl palmitate with isobutanol.}

Methyl palmitate transesterification was carried out in a round flask at $85^{\circ} \mathrm{C}$ using 2.59 mmol of methyl palmitate $(0.7 \mathrm{~g}), 0.25 \mathrm{~g}$ of catalyst, $40.63 \mathrm{mmol}$ of isobutanol $(3.75$ $\mathrm{ml}$ ) and $0.2 \mathrm{~g}$ of 1-methylnaphthalene as internal standard. After $4 \mathrm{~h}$, the catalyst was filtered off and washed with $\mathrm{CH}_{2} \mathrm{Cl}_{2}$. The crude reaction mixture was analyzed by gas chromatography using the same apparatus as in transesterification of sunflower oil. Injector temperature: $250^{\circ} \mathrm{C}$; detector temperature: $280^{\circ} \mathrm{C}$; oven program: initial temperature $200{ }^{\circ} \mathrm{C}(10 \mathrm{~min})$ rate $5^{\circ} \mathrm{C} / \mathrm{min}$, final temperature $250^{\circ} \mathrm{C}(10 \mathrm{~min})$. Retention times: 1-methylnaphthalene (standard) $2.3 \mathrm{~min}$, methyl palmitate $6.7 \mathrm{~min}$, isobutyl palmitate $12.2 \mathrm{~min}$. 


\section{Results and Discussion}

\subsection{Mg-Zn-Al mixed oxides}

\section{a) Preparation and characterization}

$\mathrm{Mg}-\mathrm{Al}$ mixed oxide with $\mathrm{Mg} / \mathrm{Al}$ ratio of 9 was chosen as starting point, given the good results obtained with this solid in previous work [14]. Zn was introduced to substitute part of the $\mathrm{Mg}$, and two solids were prepared by co-precipitation method at constant $\mathrm{pH}$ $=10, \mathrm{Mg}_{8} \mathrm{Zn}_{1} \mathrm{Al}_{1}(10)$ and $\mathrm{Mg}_{4} \mathrm{Zn}_{5} \mathrm{Al}_{1}(10)$. The $\mathrm{pH}$ was controlled by means of a $\mathrm{Na}_{2} \mathrm{CO}_{3} / \mathrm{NaOH}$ solution. The precipitated precursor showed several crystalline phases (Figure 1A), including $\mathrm{ZnO}$, hydrotalcite structure with low crystallinity, and $\mathrm{NaNO}_{3}$, together with other unidentified peaks. The thoroughly washed material is composed only by $\mathrm{ZnO}$ and hydrotalcite with lower crystallinity than in the poorly washed material. In the case of the poorly washed precursor, calcination gives rise to a highly crystalline solid (Figure 1B), containing at least three identified crystalline species, $\mathrm{ZnO}, \mathrm{MgO}$ and $\mathrm{NaNO}_{3}$, whereas the thoroughly washed precursor produces only $\mathrm{ZnO}$ and poorly crystalline $\mathrm{MgO}$.

\section{Figure 1 near here}

The adequate incorporation of $\mathrm{Zn}, \mathrm{Mg}$, and $\mathrm{Al}$ within the mixed oxides was verified by elemental analysis. All the ratios (Table 1) were in good agreement with the composition of the starting solutions, demonstrating the suitability of the precipitation conditions. Unwashed (only filtered) $\mathrm{Mg}-\mathrm{Zn}-\mathrm{Al}$ mixed oxides retain an important amount of sodium from the precipitation solution, and thorough washing with a huge amount of water is necessary in order to eliminate almost completely $(\leq 0.25 \mathrm{mmol} / \mathrm{g})$ the traces of $\mathrm{Na}$ present in the solids [3]. Solids with high sodium content present a very 
low surface area, whereas the thoroughly washed solids show values in the expected range for $\mathrm{Mg}$-Al mixed oxides. The disappearance of the highly crystalline $\mathrm{NaNO}_{3}$ phase, together with the lower crystallinity of the remaining phases after thorough washing may account for this effect on surface area.

\section{Table 1 near here}

Several $\mathrm{Zn}-\mathrm{Al}$ solids without $\mathrm{Mg}$ were prepared under different conditions. A solid with $\mathrm{Zn} / \mathrm{Al}=4$ was prepared using the same procedure at $\mathrm{pH} 10$. As $\mathrm{Zn}$ is less basic than $\mathrm{Mg}$, lower $\mathrm{pH}$ can be used to precipitate the mixed hydroxide, and a solid with the same composition was prepared at $\mathrm{pH}$ 7. As can be seen in Fig. 2 both solids show completely different crystallinity. $\mathrm{Zn}_{4} \mathrm{Al}_{1}(10)$ (Fig. 2A) is a well crystallized hydrotalcite, that retains $\mathrm{NaNO}_{3}$ together with other crystalline materials before thorough washing. $\mathrm{Zn}_{4} \mathrm{Al}_{1}(7)$ (Fig. $2 \mathrm{~B}$ ) is a poorly crystalline solid, with different $\mathrm{Zn}$ species, such as $\mathrm{Zn}(\mathrm{OH})_{2}$ and $\mathrm{Zn}_{5}\left(\mathrm{CO}_{3}\right)_{2}(\mathrm{OH})_{6}$, in which hydrotalcite is only detectable after washing.

\section{Figure 2 near here}

Calcination of all those precursors mainly produced $\mathrm{ZnO}$ with low crystallinity (Fig. 3), with almost no influence of the structure of the precursor. The $\mathrm{Zn} / \mathrm{Al}$ ratio (Table 1) was consistent with the composition of the solution, and the sodium amount in as-prepared solids was lower than in the $\mathrm{Mg}-\mathrm{Zn}-\mathrm{Al}$ solids and even lower when the synthesis was carried out at neutral $\mathrm{pH}$.

\section{Figure 3 near here}

Another solid with $\mathrm{Zn} / \mathrm{Al}=1$ was prepared also at neutral $\mathrm{pH}$. The structure was similar to that of $\mathrm{Zn}_{4} \mathrm{Al}_{1}(7)$, but with lower crystallinity (not shown). Composition of the assynthesized solid was in agreement with the initial solution, but thorough washing reduced the amounts of both $\mathrm{Al}$ and $\mathrm{Na}$ (Table 1). 
Trying to control the $\mathrm{Na}$ amount just in the as-synthesized precursor, another solid $\mathrm{Zn}_{4} \mathrm{Al}_{1}\left(7-\mathrm{NH}_{4}\right)$ was prepared maintaining the $\mathrm{pH}$ first with $\mathrm{Na}_{2} \mathrm{CO}_{3}$ until a theoretical $\mathrm{Na}$ content of $2 \mathrm{mmol} / \mathrm{g}$ in the final solid, and then with $\mathrm{NH}_{4} \mathrm{OH}$. This precursor shows the peaks corresponding to $\mathrm{Zn}(\mathrm{OH})_{2}$ and $\mathrm{Zn}_{5}\left(\mathrm{CO}_{3}\right)_{2}(\mathrm{OH})_{6}$ species (Fig. 4Aa), whereas the hydrotalcite structure is only clearly visible after thorough washing (Fig. 4Ab). After calcination (Fig. 4B) highly crystalline $\mathrm{ZnO}$ is easily identified in the case of the poorly washed precursor. As expected this solid contained much lower amount of $\mathrm{Na}$ than the analogous prepared with $\mathrm{Na}_{2} \mathrm{CO}_{3} / \mathrm{NaOH}$ (Table 1).

\section{Figure 4 near here}

The total number of basic sites was determined by titration with benzoic acid using phenolphthalein as indicator in toluene. Leachable basicity was determined by washing the solid in water and titration of the leachate also with benzoic acid and phenolphthalein. Results are gathered in Table 2. As can be seen, the as-prepared Zn-Al solids show high basicity, both total and leachable, in agreement with the high sodium content (Table 1). However there is no direct correlation between both magnitudes, demonstrating the different nature of the sites involved. The big exception is the case of $\mathrm{Mg}-\mathrm{Zn}-\mathrm{Al}$ solids, whose total basicity is very low, in contrast with the high leachable basicity. This may be due to the very low surface area of the solids $\left(<3 \mathrm{~m}^{2} / \mathrm{g}\right)$, which hides the sodium sites inside the structure and prevents the titration in toluene, whereas water washing is able to leach those sites. Thoroughly washed solids show in general values of leachable basicity below the limit of $0.15 \mathrm{mmol} / \mathrm{g}$, necessary to obtain good catalytic results in the case of $\mathrm{Mg}-\mathrm{Al}$ mixed oxides [14].

$$
\text { Table } 2 \text { near here }
$$

\section{b) Transesterification of methyl palmitate with isobutanol.}


As the catalytic activity of (Mg)-Zn-Al mixed oxides in transesterification of oils had been already demonstrated in the literature [9,16-18], these solids were tested in a more demanding reaction, the transesterification reaction of methyl palmitate with isobutanol (Scheme 1), a branched primary alcohol [14]. Results are gathered in Table 3.

\section{Scheme 1 near here \\ Table 3 near here}

As the best results with $\mathrm{Mg}-\mathrm{Al}$ mixed oxides had been obtained with $\mathrm{Mg}_{9} \mathrm{Al}_{1}(10)$, the first tests were carried out with Zn-containing solids keeping constant the $\mathrm{M}(\mathrm{III}) / \mathrm{M}(\mathrm{II})$ ratio. Both solids, $\mathrm{Mg}_{8} \mathrm{Zn}_{1} \mathrm{Al}_{1}(10)$ and $\mathrm{Mg}_{4} \mathrm{Zn}_{5} \mathrm{Al}_{1}(10)$, showed rather low catalytic activity, in spite of the high sodium content (Table 1). The disagreement between $\mathrm{Na}$ content, total basicity, leachable basicity and catalytic activity may come from the different nature of the media in which those measurements are carried out. In toluene, the highly crystalline species (Fig. 1Ba) are completely insoluble and the low surface area leads to a very low total basicity determined on the surface. In the transesterification medium, the solubility is higher, leading to a partial leaching of species and a catalytic activity higher than that of the solids with similar total basicity, such as the thoroughly washed $\mathrm{Zn}_{4} \mathrm{Al}_{1}$ solids (both prepared at $\mathrm{pH} 10$ and 7). However, given the high solubility of the crystalline species in water, the leachable basicity is much higher in the solids with very high $\mathrm{Na}$ content, a result which has no correspondence with the catalytic activity in a different medium. The thoroughly washed solids led to even worse results, in agreement with their greatly reduced basicity, both leachable and total.

On the contrary as-prepared $\mathrm{Zn}_{4} \mathrm{Al}_{1}(10)$, with high sodium content and very high leachable basicity, showed as expected very high catalytic activity. With this solid was possible to reduce both the excess of isobutanol and the reaction temperature. However, 
the thoroughly washed solid, with leachable basicity below the $0.15 \mathrm{mmol} / \mathrm{g}$ limit, lost almost completely the catalytic activity. In the case of $\mathrm{Zn}_{4} \mathrm{Al}_{1}(7)$, the lower $\mathrm{pH}$ produced a reduction in the sodium content of the as-prepared solid, from 4.5 to 2.3 $\mathrm{mmol} / \mathrm{g}$ (Table 1), and also in the leachable basicity, from 2.60 to $0.94 \mathrm{mmol} / \mathrm{g}$ (Table 2). However this new solid also showed very high activity (Table 3), even at mild reaction conditions, activity that again disappeared after thoroughly washing. A similar result was obtained with a different composition, $\mathrm{Zn}_{1} \mathrm{Al}_{1}(7)$.

The sodium content in the as-prepared solid was further reduced in $\mathrm{Zn}_{4} \mathrm{Al}_{1}\left(7-\mathrm{NH}_{4}\right)$. As a consequence this solid showed much lower catalytic activity that utterly disappeared after thorough washing.

A simulation of the role of $\mathrm{Na}$ ions was carried out by doping of the thoroughly washed $\mathrm{Zn}_{4} \mathrm{Al}_{1}(7)$ and $\mathrm{Zn}_{1} \mathrm{Al}_{1}(7)$ with different amounts of sodium salts, followed by calcination. The results of catalytic activity are gathered in Table 4.

\section{Table 4 near here}

As can be seen the post-synthesis addition of $\mathrm{Na}$ is not able to reproduce the high catalytic activity of the as-prepared solids with similar $\mathrm{Na}$ content. $\mathrm{Na}_{2} \mathrm{CO}_{3}$ and $\mathrm{NaNO}_{3}$ are the most efficient sodium salts for this purpose. Given that the optimal catalytic activity is obtained with solids containing $2.3-4.5 \mathrm{mmol} \mathrm{Na} / \mathrm{g}$, a value in this range $(3.75 \mathrm{mmol} / \mathrm{g})$ was chosen as optimal loading. In fact this seems to be also the case with added $\mathrm{Na}$, given the detrimental effect of either lower loading $(0.95 \mathrm{mmol} / \mathrm{g})$ or larger excess of $\mathrm{Na}(5.66$ or $7.55 \mathrm{mmol} / \mathrm{g})$. A poorer $\mathrm{Na}$ dispersion on the surface may account for this effect. The role of sodium on the activity of mixed oxides is again confirmed in the case of $\mathrm{Mg}$ is substituted by $\mathrm{Zn}$ as divalent metal, either in part or completely.

\subsection{Mg-M(III) mixed oxides}




\section{a) Preparation and characterization}

Once proved the role of alkaline cations in different $\mathrm{M}(\mathrm{II}) / \mathrm{Al}$ mixed oxides, aluminum was substituted by other trivalent metals, gallium and lanthanum, in another set of experiments to test the generality of the alkaline effect on the strong basicity of mixed oxides. All the $\mathrm{Mg} / \mathrm{M}(\mathrm{III})$ solids were prepared by co-precipitation method at constant $\mathrm{pH}$. A $\mathrm{M}(\mathrm{III}) /(\mathrm{Mg}+\mathrm{M}(\mathrm{III}))$ ratio of 0.1 was chosen due to the fact that previous results with Mg-Al mixed oxides indicated a maximum activity for this solid composition [14]. Elemental analysis was used to determine the adequate incorporation of $\mathrm{M}(\mathrm{III})$ and $\mathrm{Mg}$. All the ratios (Table 5) were in good agreement with the composition of the starting solutions. The co-precipitation method involves the use of sodium salts solutions and, as observed for the solids containing $\mathrm{Zn}$, in all cases a certain amount of sodium remains in the solids even after thorough washing. In view of that, a solid free from sodium, $\mathrm{Mg}_{9} \mathrm{La}_{1}\left(\mathrm{NH}_{4}\right)$, was also prepared using ammonium bases as co-precipitation medium.

\section{Table 5 near here}

The structures of the precursors and the mixed oxides were studied by XRD (Figure 5). The hydrotalcite structure was identified in the precursors containing $\mathrm{Al}$ and $\mathrm{Ga}$, whereas this type of structure was not observable in the case of $\mathrm{Mg}_{9} \mathrm{La}_{1}$ precursor. After calcination, the peaks corresponding to $\mathrm{MgO}$ were apparent in all the solids. A broad peak from $2 \theta=20$ to 34 seemed to indicate also the presence of an amorphous phase, more important in the case of Al- and Ga-containing solids. In the case of the solids containing lanthanum, calcination at $773 \mathrm{~K}$ did not seem to be enough to obtain a mixed oxide, since a peak corresponding to $\mathrm{La}_{2}\left(\mathrm{CO}_{3}\right)_{3}(2 \theta=29)$ was still present (Fig. 5Ba). In the thermogravimetric analysis of this solid, the DTGA curve showed losses of weight at $523 \mathrm{~K}(10.5 \%)$, at $713 \mathrm{~K}(35.0 \%)$, and a residual loss of $3.5 \%$ at $873 \mathrm{~K}$. This result 
indicated the need of calcination above $873 \mathrm{~K}$ for a total decomposition of carbonate species. XRD patterns of the solid calcined at $973 \mathrm{~K}$ showed good crystallinity and typical signals of mixed $\mathrm{Mg} / \mathrm{La}$ oxide, $\mathrm{La}_{2} \mathrm{O}_{3}$ and $\mathrm{MgO}$ (Figure 6).

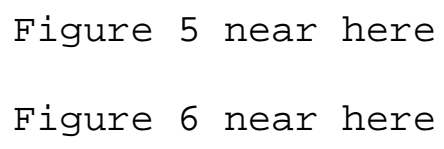

Total basicity and leachable basicity were again determined by titration with benzoic acid using phenolphthalein as indicator. Results are gathered in table 6. As can be seen, those solids containing a significant sodium amount also present a significant leachable basicity. In the case of low or no sodium content, the solids still showed a residual leachable basicity $(<0.1 \mathrm{mmol} / \mathrm{g})$, the same tendency observed for $\mathrm{Zn}$ containing solids.

\section{Table 6 near here}

The influence of the presence of sodium in the leachable basicity was demonstrated by the good correlation observed when representing both parameters for $\mathrm{Mg}_{9} \mathrm{M}(\mathrm{III})_{1}$ solids (Figure 7), whereas no correlation can be found for total basicity and sodium content.

\section{Figure 7 near here}

\section{b) Transesterification of sunflower oil with methanol}

The transesterification of sunflower oil with methanol (Scheme 2) was used as reaction test for $\mathrm{Mg}_{9} \mathrm{M}(\mathrm{III})_{1}$ catalysts. Results of fatty acid methyl ester (FAME) yields are gathered in Table 7.

\section{Scheme 2 near here Table 7 near here}

As can be seen, all the catalysts prepared with sodium bases, and hence containing a significant amount of $\mathrm{Na}$ (see Table 5), show a very high catalytic activity in the sunflower oil transesterification, with almost quantitative yields both cases. On the 
contrary, solids with low sodium content or the solid prepared with ammonium bases presents very poor activity irrespectively of the nature of the trivalent metal in the solid. Those results do not show any correlation with total basicity of solids, determined by titration with indicators of different acidity (Table 6). In fact the solid prepared with ammonium bases shows a number of basic sites close to the maximum. But these results clearly show that the presence of a minimum amount of alkaline ions and therefore a leachable basicity over $0.1 \mathrm{mmol} / \mathrm{g}$ is compulsory to achieve moderate to good yields in transesterification of sunflower oil.

The recovery of the solids without reactivation led to very poor catalytic activity. However, calcination under the same conditions allows an efficient recovery, but activity drops from the third run. This fact was carefully studied for the catalyst $\mathrm{Mg}_{9} \mathrm{La}_{1}$ and the loss of activity was closely related to the decrease of sodium content in the solid, from $90 \%$ to $34 \%$ yield in the fourth run and from $0.22 \mathrm{mmol} \mathrm{Na} / \mathrm{g}$ in the fresh catalyst to $0.08 \mathrm{mmol} \mathrm{Na} / \mathrm{g}$ in the recovered one.

Relationship between sodium content and activity was even more evident when the solids were used as catalysts in a more demanding transesterification reaction such as the reaction of methyl palmitate with isobutanol (Scheme 1). As can be seen in Figure 8, moderate to high yields can be obtained in this reaction only with catalysts having sodium content over $0.22 \mathrm{mmol}$ per gram. Catalysts with low or no sodium content exhibited yields under 5\%. This fact demonstrated the need of the presence of alkaline ions in the mixed oxides for a good activity in transesterification reactions.

\section{Figure 8 near here}

\section{Conclusions}


The source of strong basicity in M(II)-M(III) mixed oxides is always the presence of traces of alkaline cations from the precipitation medium, irrespective from the nature of both $\mathrm{M}(\mathrm{II})(\mathrm{Mg}$ or $\mathrm{Zn}$ ) and $\mathrm{M}(\mathrm{III})$ (Al, Ga or La). This is very clear with highly demanding reactions with respect to basicity, as some transesterification reactions such as that of methyl palmitate with isobutanol. In this reaction solids free from alkaline cations are completely inactive under mild conditions, whereas they are still partially active in the less demanding transesterification of sunflower oil with methanol. The basic sites corresponding to residual alkaline cations are leachable to solution, and the degree of leaching depends on the nature of the reaction medium. This slow release of alkaline to solution under reaction conditions allows only a partial recovery of the catalyst, with irreversible deactivation of the strong alkaline-based sites. These results show the intrinsic limitation of alkaline-free mixed oxides as catalysts for this kind of demanding reactions.

\section{Acknowledgements}

This work was made possible by the financial support of the Ministerio de Educación y Ciencia (projects CTQ2008-05138 and Consolider Ingenio 2010 CSD2006-0003).

\section{References}

[1] H. Hattori, Chem. Rev. 95 (1995) 537-558.

[2] F. Cavani, F. Trifiro, A. Vaccari, Catal. Today 11 (1991) 173-301.

[3] D. P. Debecker, E. M. Gaigneaux, G. Busca, Chem. Eur. J. 15 (2009) 3920-3935.

[4] D. G. Cantrell, L. J. Gillie, A. F. Lee, K. Wilson, Appl. Catal. A 287 (2005) 183190.

[5] W. Xie, H. Peng, L. Chen, J. Mol. Catal. A 246 (2006) 24-32. 
[6] Y. Liu, E. Lotero, J. G. Goodwin Jr., X. Mo, Appl. Catal A 331 (2007) 138-148.

[7] M. C. G. Albuquerque, J. Santamaría-González, J. M. Mérida-Robles, R. MorenoTost, E. Rodríguez-Castellón, A. Jiménez-López, D. C. S. Azevedo, C. L. Cavalcante Jr., P. Maireles-Torres, Appl. Catal. A 347 (2008) 162-168.

[8] H. Zeng, Z. Feng, X. Deng, Y. Li, Fuel 87 (2008) 3071-3076.

[9] W. M. Antunes, C. O. Veloso, C. A. Henriques, Catal. Today 133-135 (2008) 548554.

[10] G. S. Macala, A. W. Robertson, C. L. Johnson, Z. B. Day, R. S. Lewis, M. G. White, A. V. Iretskii, P. C. Ford, Catal. Lett. 122 (2008) 205-209.

[11] T. Tittabutt, W. Trakarnpruk, Ind. Eng. Chem. Res. 47 (2008) 2176-2181.

[12] J. I. Di Cosimo, V. K. Diez, M. Xu, E. Iglesia, C. R. Apesteguía, J. Catal. 178 (1998) 499-510.

[13] A. L. McKenzie, C. T. Fishel, R. J. Davis, J. Catal. 138 (1992) 547-561.

[14] J. M. Fraile, N. García, J. A. Mayoral, E. Pires, L. Roldán, Appl. Catal. A 364(2009) 87-94.

[15] S. Abelló, F. Medina, D. Tichit, J. Pérez-Ramírez, X. Rodríguez, J. E. Sueiras, P. Salagre, Y. Cesteros, Appl. Catal. A 281 (2005) 191-198.

[16] R. Stern, G. Hillion, J.-J. Rouxel, S. Leporq, US Patent 5,908,946 (1999).

[17] L. Bournay, D. Casanave, B. Delfort, G. Hillion, J. A. Chodorge, Catal. Today 106 (2005) 190-192.

[18] C. C. S. Macedo, F. R. Abreu, A. P. Tavares, M. B. Alves, L. F. Zara, J. C. Rubim, P. A. Z. Suarez, J. Braz. Chem. Soc. 17 (2006) 1291-1296.

[19] N. S. Babu, R. Sree, P. S. S. Prasad, N. Lingaiah, Energy Fuels 22 (2008) 19651971. 
[20] J. Wahlen, D. E. De Vos, P. A. Jacobs, V. Nardello, J.-M. Aubry, P. L. Alsters, J. Catal. 249 (2007) 15-23.

[21] F. M. P. R. van Laar, D. E. De Vos, F. Pierard, A. Kirsch-De Mesmaeker, L. Fiermans, P. A. Jacobs, J. Catal. 197 (2001) 139-150. 
Table 1. Composition and surface area of Mg-Zn-Al mixed oxides.

\begin{tabular}{|c|c|c|c|c|c|c|}
\hline \multirow[b]{2}{*}{ Catalyst } & \multicolumn{2}{|c|}{$\mathrm{Al} /(\mathrm{Mg}+\mathrm{Zn}+\mathrm{Al})$} & \multicolumn{2}{|c|}{$\mathrm{Mg} / \mathrm{Zn}$} & \multirow{2}{*}{$\begin{array}{l}\text { Na content } \\
(\mathrm{mmol} / \mathrm{g})\end{array}$} & \multirow{2}{*}{$\begin{array}{c}\text { Surface area } \\
\qquad\left(\mathrm{m}^{2} / \mathrm{g}\right)\end{array}$} \\
\hline & Theoretical & Experimental & Theoretical & Experimental & & \\
\hline $\mathrm{Mg}_{9} \mathrm{Al}_{1}(10)$ & 0.10 & 0.12 & - & - & 1.22 & 96 \\
\hline thoroughly washed & 0.10 & 0.10 & - & - & 0.02 & 172 \\
\hline $\mathrm{Mg}_{8} \mathrm{Zn}_{1} \mathrm{Al}_{1}(10)$ & 0.10 & 0.10 & 8.00 & 7.60 & 27.98 & 2 \\
\hline thoroughly washed & 0.10 & 0.11 & 8.00 & 6.85 & 0.25 & 176 \\
\hline $\mathrm{Mg}_{4} \mathrm{Zn}_{5} \mathrm{Al}_{1}(10)$ & 0.10 & 0.10 & 0.80 & 0.88 & 12.10 & 3 \\
\hline thoroughly washed & 0.10 & 0.10 & 0.80 & 0.85 & 0.11 & 95 \\
\hline $\mathrm{Zn}_{4} \mathrm{Al}_{1}(10)$ & 0.20 & 0.20 & - & - & 4.49 & 26 \\
\hline thoroughly washed & 0.20 & 0.21 & - & - & 0.23 & 98 \\
\hline $\mathrm{Zn}_{4} \mathrm{Al}_{1}(7)$ & 0.20 & 0.20 & - & - & 2.29 & 43 \\
\hline thoroughly washed & 0.20 & 0.19 & - & - & 0.25 & 102 \\
\hline $\mathrm{Zn}_{1} \mathrm{Al}_{1}(7)$ & 0.50 & 0.52 & - & - & 3.56 & 31 \\
\hline thoroughly washed & 0.50 & 0.36 & - & - & 0.03 & 119 \\
\hline $\mathrm{Zn}_{4} \mathrm{Al}_{1}\left(7-\mathrm{NH}_{4}\right)$ & 0.20 & 0.15 & - & - & 0.78 & 85 \\
\hline thoroughly washed & 0.20 & 0.21 & - & - & 0.02 & 124 \\
\hline
\end{tabular}


Table 2. Basicity of Mg-Zn-Al mixed oxides.

\begin{tabular}{ccc}
\hline Catalyst & $\begin{array}{c}\text { Total basicity } \\
(\mathrm{mmol} / \mathrm{g})\end{array}$ & $\begin{array}{c}\text { Leachable basicity } \\
(\mathrm{mmol} / \mathrm{g})\end{array}$ \\
\hline $\mathrm{Mg}_{9} \mathrm{Al}_{1}(10)$ & 0.51 & 0.21 \\
thoroughly washed & 0.50 & 0.14 \\
$\mathrm{Mg}_{8} \mathrm{Zn}_{1} \mathrm{Al}_{1}(10)$ & 0.13 & 4.28 \\
thoroughly washed & 0.26 & 0.21 \\
$\mathrm{Mg}_{4} \mathrm{Zn}_{5} \mathrm{Al}_{1}(10)$ & 0.11 & 3.55 \\
thoroughly washed & 0.21 & 0.17 \\
$\mathrm{Zn}_{4} \mathrm{Al}_{1}(10)$ & 1.70 & 2.60 \\
thoroughly washed & 0.15 & 0.07 \\
$\mathrm{Zn}_{4} \mathrm{Al}_{1}(7)$ & 1.06 & 0.94 \\
thoroughly washed & 0.17 & 0.07 \\
$\mathrm{Zn}_{1} \mathrm{Al} l_{1}(7)$ & 2.13 & 0.85 \\
thoroughly washed & 0.28 & 0.03 \\
$\mathrm{Zn}_{4} \mathrm{Al}_{1}\left(7-\mathrm{NH}{ }_{4}\right)$ & 0.25 & 0.11 \\
thoroughly washed & 0.40 & 0.01 \\
\hline
\end{tabular}


Table 3. Results from transesterification reaction of methyl palmitate with isobutanol catalyzed by Mg-Zn-Al mixed oxides.

\begin{tabular}{ccccc}
\hline Catalyst & $\begin{array}{c}\text { iBuOH/ } \\
\text { palmitate }\end{array}$ & Temp. $\left({ }^{\circ} \mathrm{C}\right)$ & Yield $(1 \mathrm{~h})$ & Yield $(4 \mathrm{~h})$ \\
\hline $\mathrm{Mg}_{9} \mathrm{Al}_{1}(10)$ & 16 & 85 & 78 & 98 \\
thoroughly washed & 16 & 85 & 7 & 12 \\
$\mathrm{Mg}_{8} \mathrm{Zn}_{1} \mathrm{Al}_{1}(10)$ & 16 & 85 & 12 & 28 \\
thoroughly washed & 16 & 85 & 10 & 21 \\
$\mathrm{Mg}_{4} \mathrm{Zn}_{5} \mathrm{Al}_{1}(10)$ & 16 & 85 & 20 & 46 \\
thoroughly washed & 16 & 85 & 2 & 6 \\
$\mathrm{Zn}_{4} \mathrm{Al}_{1}(10)$ & 16 & 85 & 99 & - \\
& 16 & 50 & 40 & 66 \\
thoroughly washed & 16 & 85 & 28 & 74 \\
$\mathrm{Zn}_{4} \mathrm{Al}_{1}(7)$ & 4 & 85 & 2 & 6 \\
& 4 & 85 & 99 & - \\
thoroughly washed & 4 & 50 & 84 & 99 \\
$\mathrm{Zn}_{1} \mathrm{Al}_{1}(7)$ & 4 & 50 & 1 & 2 \\
thoroughly washed & 4 & 50 & 90 & 95 \\
$\mathrm{Zn}_{4} \mathrm{Al}_{1}\left(7-\mathrm{NH} \mathrm{H}_{4}\right)$ & 4 & 50 & 1 & 2 \\
thoroughly washed & 4 & 50 & 5 & 12 \\
\hline
\end{tabular}


Table 4. Results from transesterification reaction of methyl palmitate with isobutanol catalyzed by Na-doped Zn-Al mixed oxides. ${ }^{\text {a }}$

\begin{tabular}{ccccc}
\hline Starting solid & $\begin{array}{c}\text { Sodium salt } \\
(\mathrm{mmol} \mathrm{Na} / \mathrm{g})\end{array}$ & $\begin{array}{c}\text { Calcination } \\
\text { temp. }\left({ }^{\circ} \mathrm{C}\right)\end{array}$ & Yield $(1 \mathrm{~h})$ & Yield (4 h) \\
\hline $\mathrm{Zn}_{4} \mathrm{Al}_{1}(7)$ & - & 530 & 1 & 2 \\
& $\mathrm{Na}_{2} \mathrm{CO}_{3}(3.75)$ & 530 & 65 & 83 \\
& reuse & 530 & 24 & 47 \\
& $\mathrm{Na}_{2} \mathrm{CO}_{3}(5.66)$ & 530 & 29 & 58 \\
& $\mathrm{CH}_{3} \mathrm{COONa}(3.75)$ & 530 & 21 & 44 \\
& $\mathrm{NaNO}_{3}(3.75)$ & 900 & 4 & 5 \\
& $\mathrm{NaNO}_{3}(3.75)$ & 530 & 51 & 74 \\
& $\mathrm{reuse}^{\mathrm{Z}}$ & 530 & 2 & 2 \\
$\mathrm{Zn}_{1} \mathrm{Al}_{1}(7)$ & - & 530 & 1 & 2 \\
& $\mathrm{Na}_{2} \mathrm{CO}_{3}(0.95)$ & 530 & 3 & 11 \\
& $\mathrm{Na}_{2} \mathrm{CO}_{3}(3.75)$ & 530 & 51 & 80 \\
& $\mathrm{Na}_{2} \mathrm{CO}_{3}(7.55)$ & 530 & 35 & 68 \\
$\mathrm{NaNO}_{3}(0.60)$ & 530 & 2 & 4 \\
\hline
\end{tabular}

${ }^{\mathrm{a}}$ Prepared from thoroughly washed solids. Reaction conditions: isobutanol $/$ palmitate $=$ $4: 1 ; 50^{\circ} \mathrm{C}$.

Table 5. Composition and surface area of $\mathrm{Mg}_{9} \mathrm{M}(\mathrm{III})_{1}$ mixed oxides.

\begin{tabular}{ccccc}
\hline Catalyst & \multicolumn{2}{c}{$\begin{array}{c}\mathrm{M}(\mathrm{III}) /(\mathrm{Mg}+\mathrm{M}(\mathrm{III})) \\
\text { Experimental }\end{array}$} & $\begin{array}{c}\text { Na content } \\
(\mathrm{mmol} / \mathrm{g})\end{array}$ & $\begin{array}{c}\text { Surface area } \\
\left(\mathrm{m}^{2} / \mathrm{g}\right)^{\mathrm{a}}\end{array}$ \\
\hline $\begin{array}{c}\mathrm{Mg}_{9} \mathrm{Al}_{1} \\
\text { Thoroughly washed }\end{array}$ & 0.10 & 0.12 & 0.24 & 96 \\
$\mathrm{Mg}_{9} \mathrm{Ga}_{1}$ & 0.10 & 0.10 & 0.02 & 169 \\
$\mathrm{Mg}_{9} \mathrm{La}_{1}{ }^{\mathrm{b}}$ & 0.10 & 0.10 & 0.03 & 52 \\
thoroughly washed $^{\mathrm{b}}$ & 0.10 & 0.12 & 0.22 & 65 \\
$\mathrm{Mg}_{9} \mathrm{La}_{1}\left(\mathrm{NH}_{4}\right)^{\mathrm{c}}$ & 0.10 & 0.12 & 0.12 & n.d. \\
\end{tabular}

${ }^{\mathrm{a}}$ n.d. $=$ not determined. ${ }^{\mathrm{b}}$ Activated by calcination at $973 \mathrm{~K}$. ${ }^{\mathrm{c}}$ Prepared with ammonium bases. 
Table 6. Basicity of $\mathrm{Mg}_{9} \mathrm{M}(\mathrm{III})_{1}$ solids.

\begin{tabular}{cccc}
\hline Catalyst & $\begin{array}{c}\text { Total basicity } \\
(\mathrm{mmol} / \mathrm{g})\end{array}$ & $\begin{array}{c}\text { Leachable basicity } \\
(\mathrm{mmol} / \mathrm{g})\end{array}$ & $\begin{array}{c}\text { Na content } \\
(\mathrm{mmol} / \mathrm{g})\end{array}$ \\
\hline $\mathrm{Mg}_{9} \mathrm{Al}_{1}$ & 0.51 & 0.19 & 0.24 \\
thoroughly washed & 0.35 & 0.01 & 0.02 \\
$\mathrm{Mg}_{9} \mathrm{Ga}_{1}$ & 0.46 & 0.06 & 0.03 \\
$\mathrm{Mg}_{9} \mathrm{La}_{1}{ }^{\mathrm{a}}$ & 0.08 & 0.22 & 0.22 \\
thoroughly washed $^{\mathrm{a}}$ & 0.09 & 0.08 & 0.12 \\
$\mathrm{Mg}_{9} \mathrm{La}_{1}\left(\mathrm{NH}_{4}\right)^{\mathrm{b}}$ & 0.41 & 0.07 & -- \\
\hline
\end{tabular}

${ }^{\mathrm{a}}$ Activated by calcination at $973 \mathrm{~K} .{ }^{\mathrm{b}}$ Solid prepared with ammonium bases.

Table 7. FAME yields in sunflower oil transesterification with methanol catalyzed by $\mathrm{Mg}_{9} \mathrm{M}(\mathrm{III})_{1}$ mixed oxides. ${ }^{\mathrm{a}}$

\begin{tabular}{cc}
\hline Catalyst & FAME yield $(3 \mathrm{~h})$ \\
\hline $\mathrm{Mg}_{9} \mathrm{Al}_{1}$ & 93.0 \\
thoroughly washed & 31.0 \\
$\mathrm{Mg}_{9} \mathrm{Ga}_{1}$ & 34.3 \\
$\mathrm{Mg}_{9} \mathrm{La}_{1}{ }^{\mathrm{b}}$ & 90.5 \\
thoroughly washed $\mathrm{Mg}_{9} \mathrm{La}_{1}\left(\mathrm{NH}_{4}\right)^{\mathrm{c}}$ & 3.8 \\
${ }^{\mathrm{a}}$ Blank reaction does not produce any measurable yield of FAME. $^{\mathrm{b}}$ Activated by \\
calcination at $973 \mathrm{~K} .{ }^{\mathrm{c}}$ Prepared with ammonium hydroxide and carbonate.
\end{tabular}




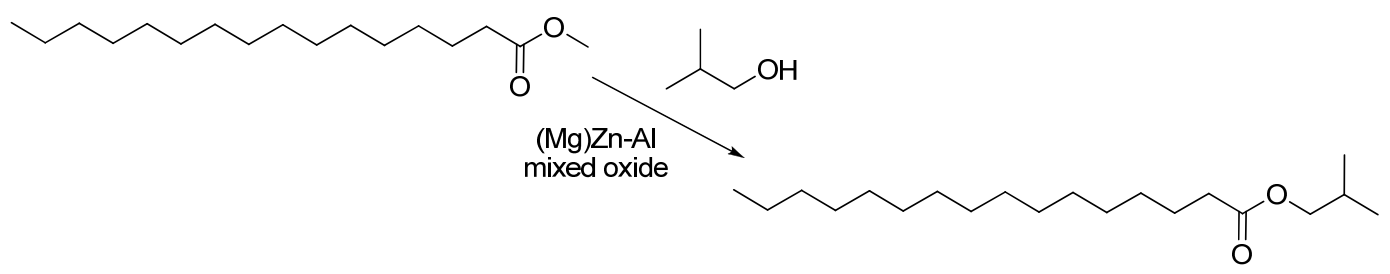

Scheme 1.Transesterification of methyl palmitate with isobutanol.

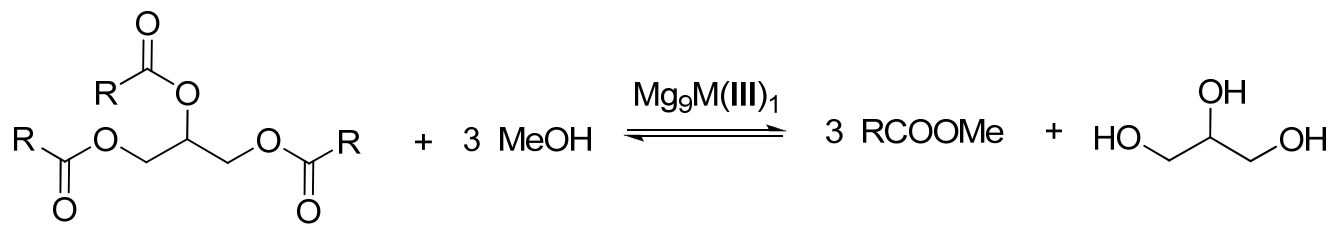

Scheme 2.Transesterification of sunflower oil with methanol. 

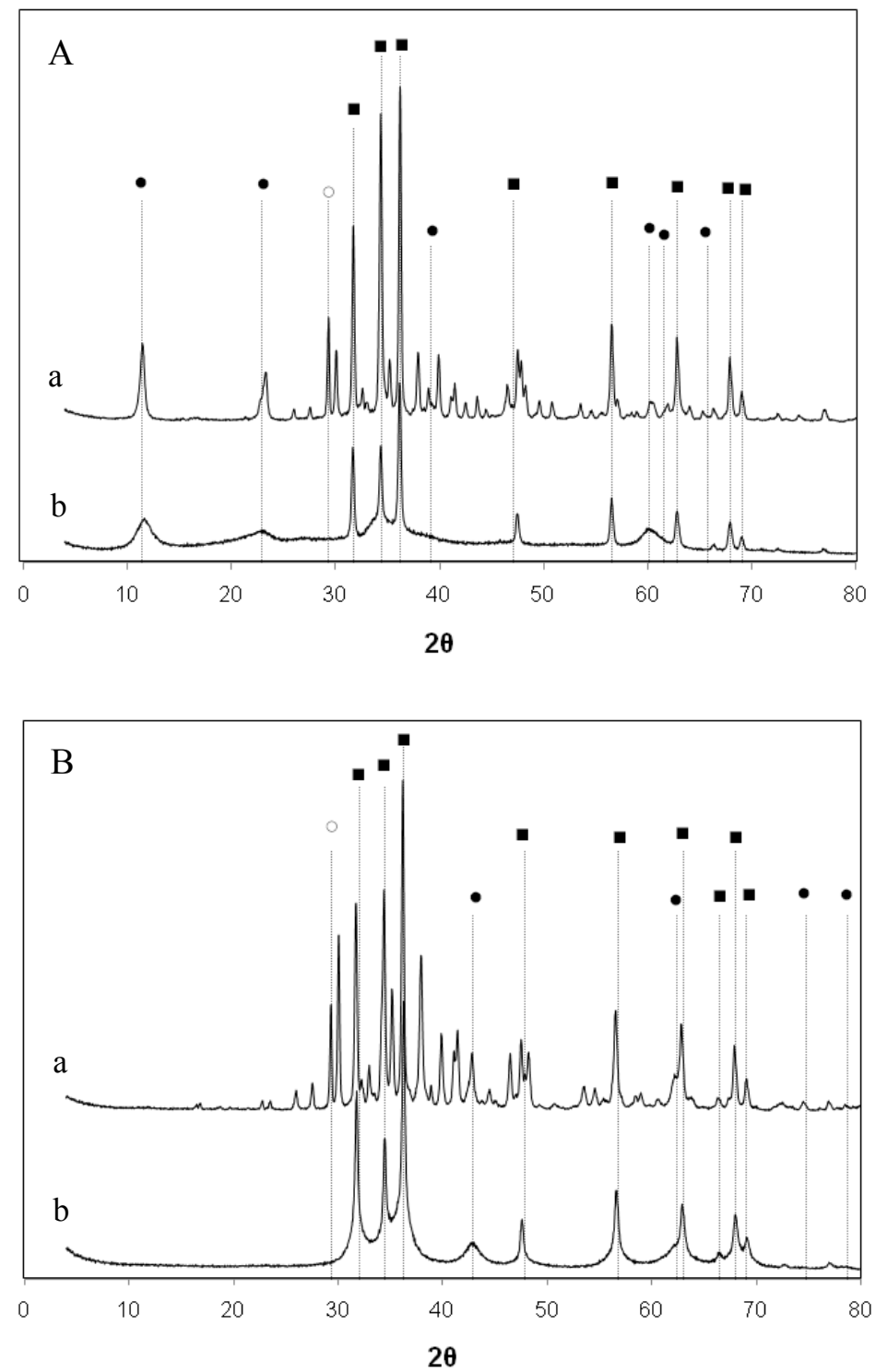

Figure 1.A) XRD patterns of $\mathrm{Mg}_{4} \mathrm{Zn}_{5} \mathrm{Al}_{1}(10)$ precursors, poorly washed (a) and thoroughly washed (b). Identified species: hydrotalcite (•), $\mathrm{NaNO}_{3}(\circ)$, and $\mathrm{ZnO}(\mathbf{\bullet})$. B)XRD patterns of $\mathrm{Mg}_{4} \mathrm{Zn}_{5} \mathrm{Al}_{1}(10)$ mixed oxides prepared by calcination of the same precursors. Identified species: $\mathrm{MgO}(\bullet), \mathrm{NaNO}_{3}(\circ)$, and $\mathrm{ZnO}(\mathbf{\bullet})$. 

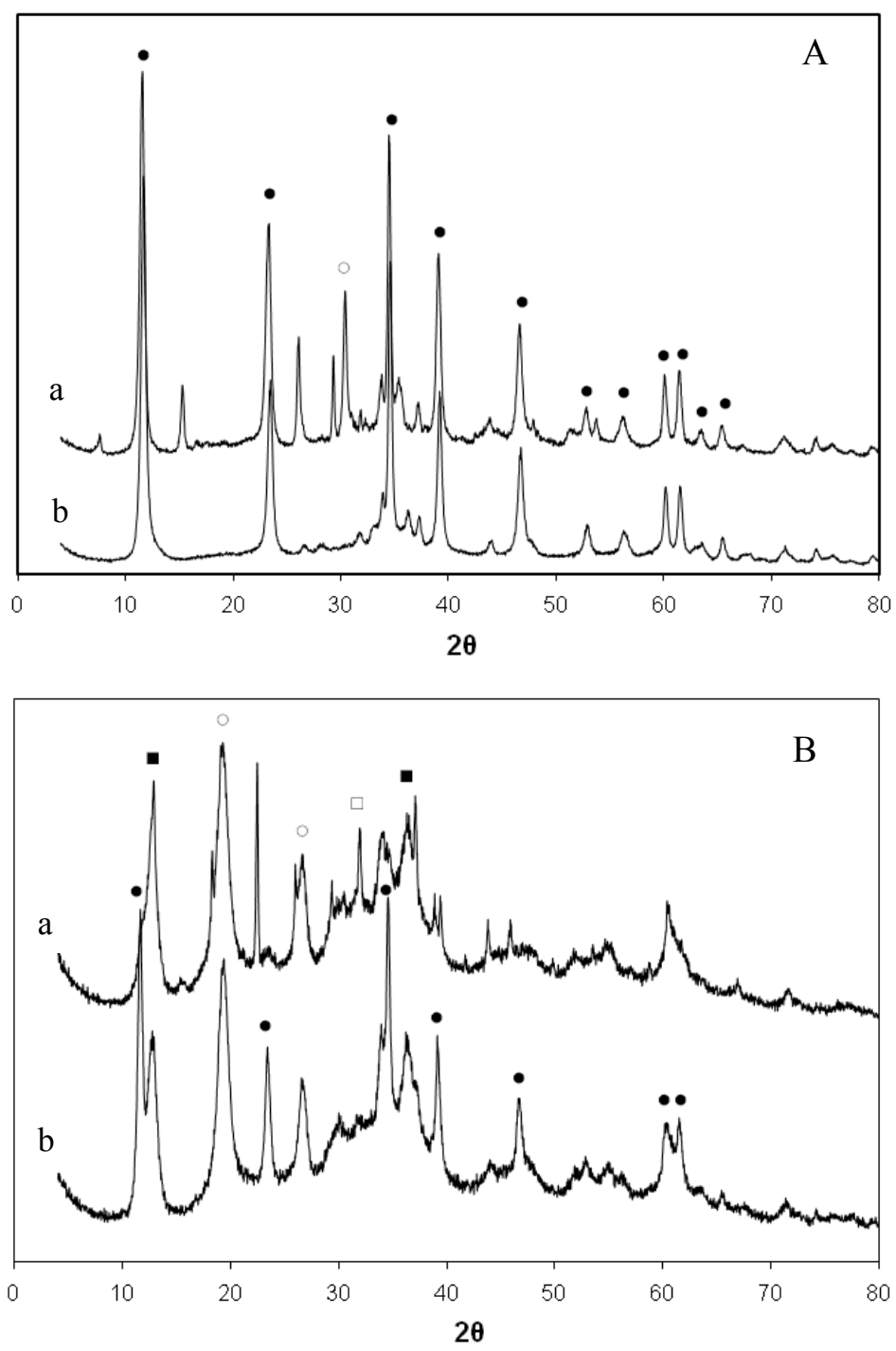

Figure 2.A) XRD patterns of $\mathrm{Zn}_{4} \mathrm{Al}_{1}(10)$ precursors, poorly washed (a) and thoroughly washed (b). Identified species: hydrotalcite (•) and $\mathrm{NaNO}_{3}(\circ)$. B) XRD patterns of $\mathrm{Zn}_{4} \mathrm{Al}_{1}(7)$ precursors, poorly washed (a) and thoroughly washed (b). Identified species: hydrotalcite $(\bullet), \mathrm{Zn}(\mathrm{OH})_{2}(\circ), \mathrm{NaNO}_{3}(\square)$, and $\mathrm{Zn}_{5}\left(\mathrm{CO}_{3}\right)_{2}(\mathrm{OH})_{6}(\mathbf{\bullet})$. 

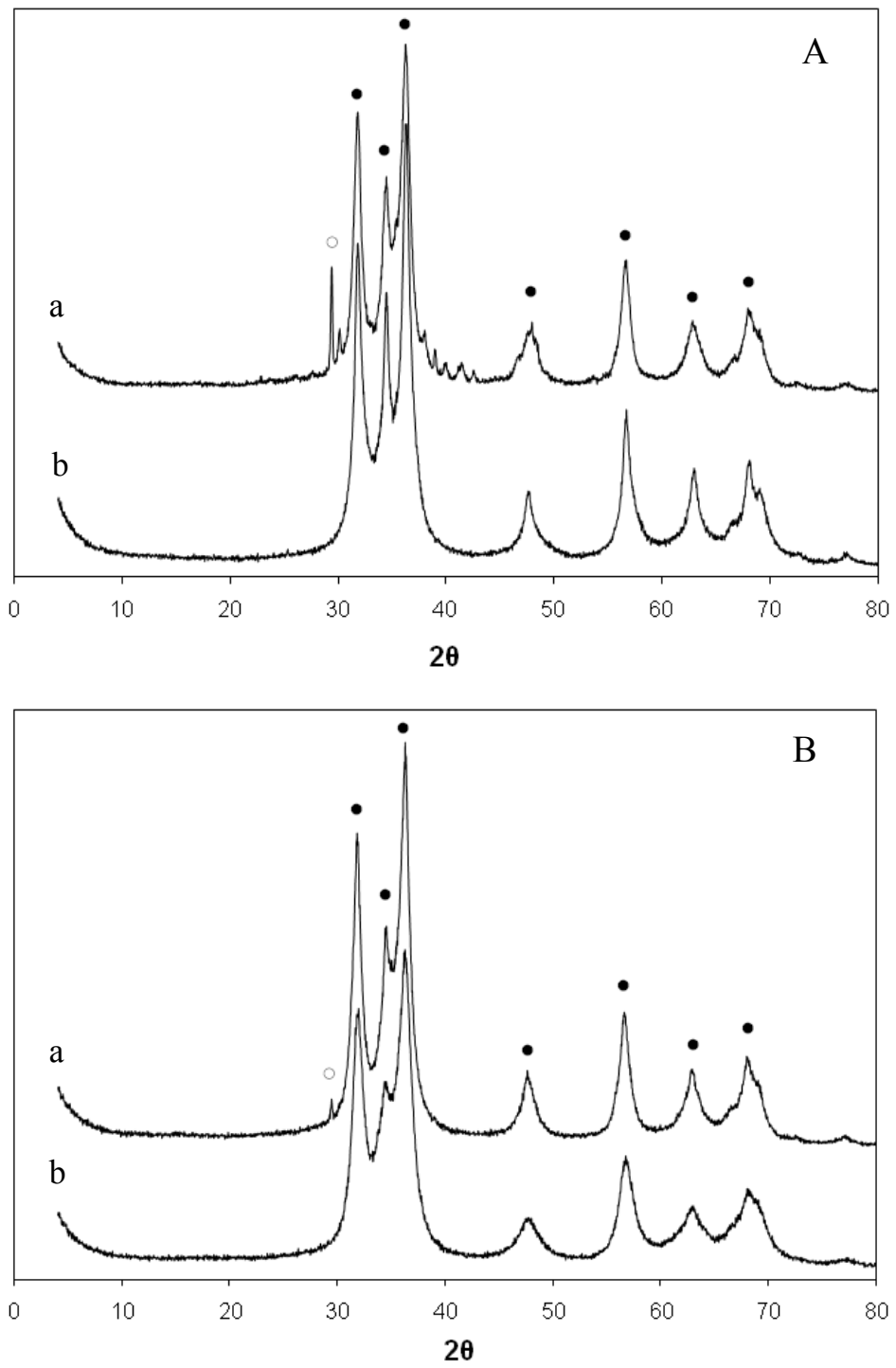

Figure 3.A) XRD patterns of $\mathrm{Zn}_{4} \mathrm{Al}_{1}(10)$ mixed oxides prepared by calcination of the precursors shown in Fig. 2A. B) XRD patterns of $\mathrm{Zn}_{4} \mathrm{Al}_{1}(7)$ mixed oxides prepared by calcination of the precursors shown in Fig. 2B. Identified species: $\mathrm{ZnO}(\bullet)$ and $\mathrm{NaNO}_{3}$ (०). 

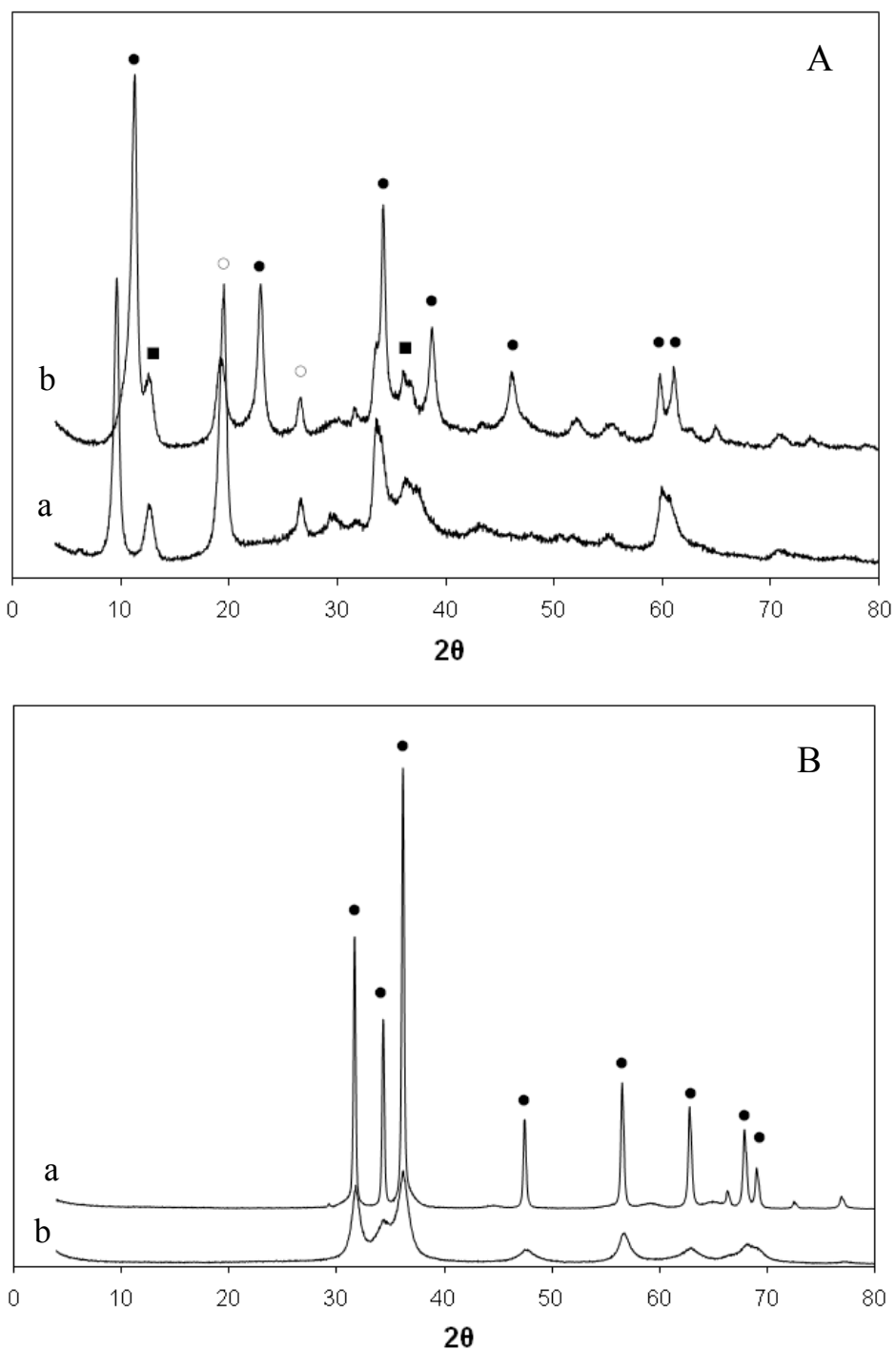

Figure 4.A) XRD patterns of $\mathrm{Zn}_{4} \mathrm{Al}_{1}\left(7-\mathrm{NH}_{4}\right)$ precursors, poorly washed (a) and thoroughly washed (b). Identified species: hydrotalcite $(\bullet), \mathrm{Zn}(\mathrm{OH})_{2}(\circ)$, and $\mathrm{Zn}_{5}\left(\mathrm{CO}_{3}\right)_{2}(\mathrm{OH})_{6}(\boldsymbol{\bullet})$. B) XRD patterns of $\mathrm{Zn}_{4} \mathrm{Al}_{1}\left(7-\mathrm{NH}_{4}\right)$ mixed oxides prepared by calcination of the same precursors. Identified species: $\mathrm{ZnO}(\bullet)$. 

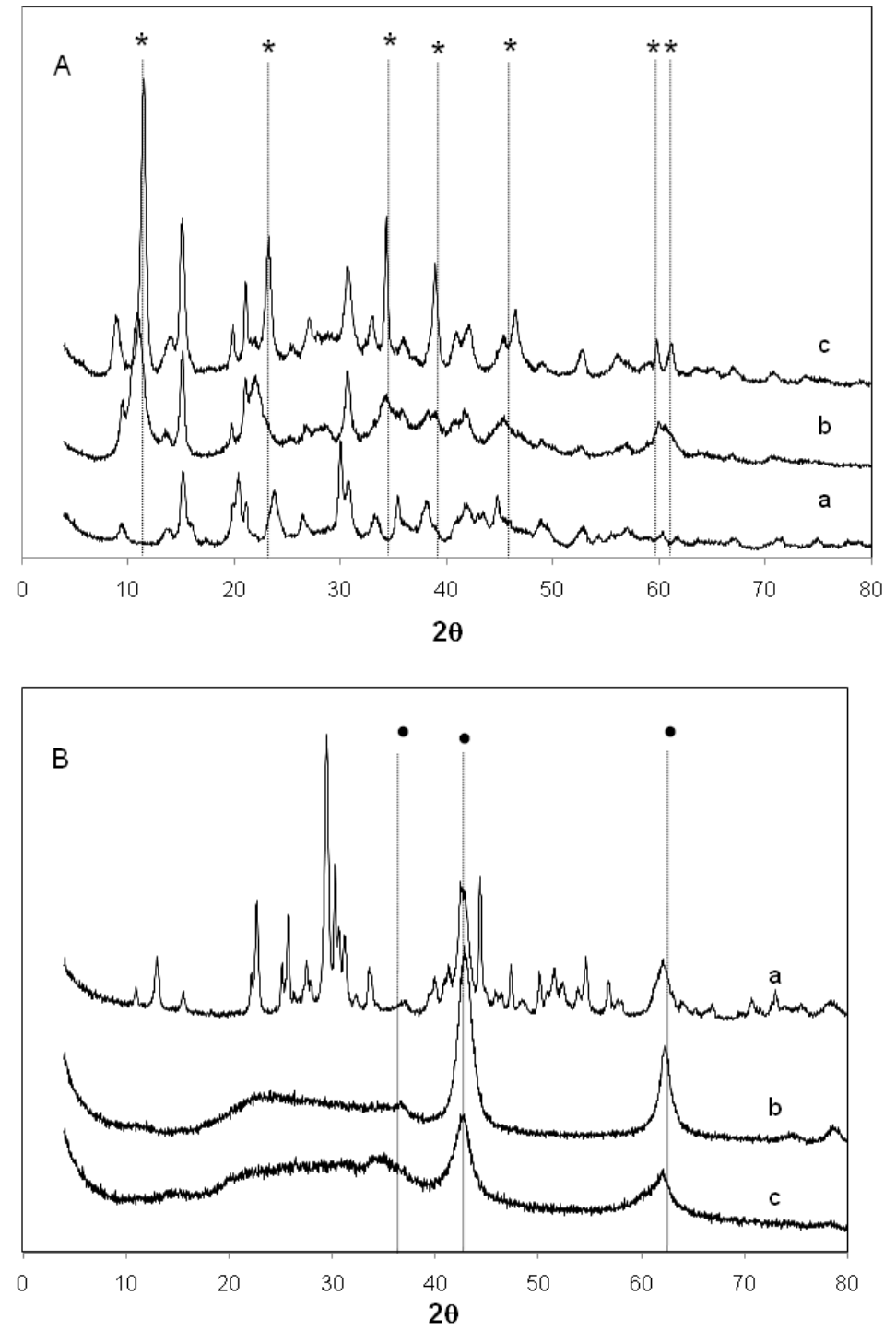

Figure 5. XRD patterns of $\mathrm{Mg} / \mathrm{M}(\mathrm{III})$ solids. a) $\mathrm{Mg}_{9} \mathrm{La}_{1}$, b) $\mathrm{Mg}_{9} \mathrm{Al}_{1}$, c) $\mathrm{Mg}_{9} \mathrm{Ga}_{1}$. A) Precursors. Identified species: hydrotalcite $\left(^{*}\right)$. B) Mixed oxides prepared by calcination at $723 \mathrm{~K}$. Identified species: $\mathrm{MgO}(\bullet)$. 


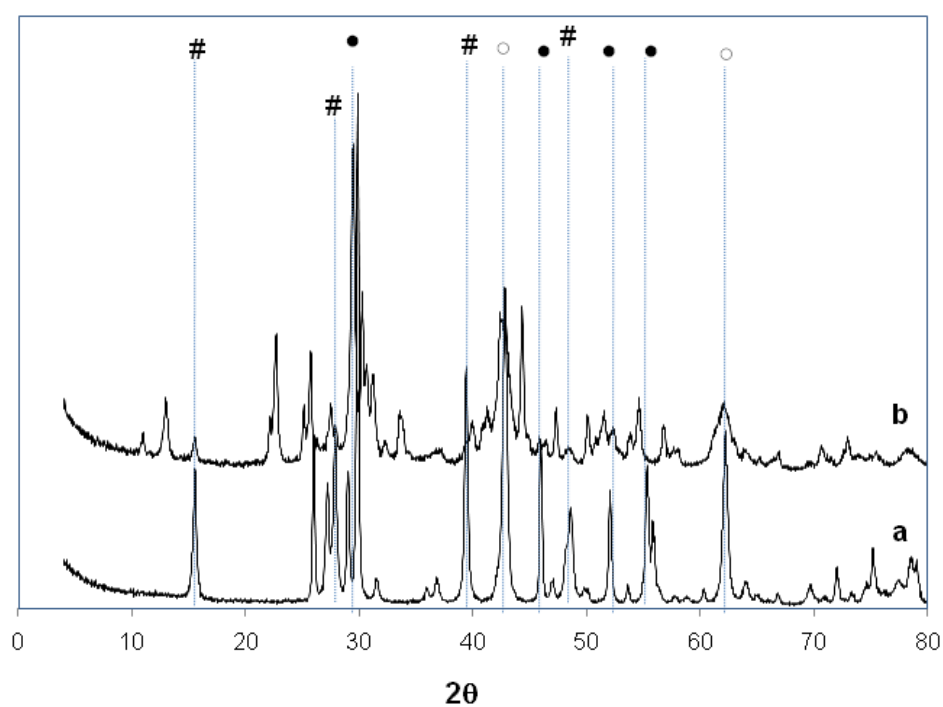

Figure 6. XRD patterns of $\mathrm{Mg}_{9} \mathrm{La}_{1}$ a) calcined at $773 \mathrm{~K}$, b) calcined at $973 \mathrm{~K}$. Identified species: $\mathrm{MgO}(\bullet), \mathrm{La}_{2} \mathrm{O}_{3}(\circ)$, and $\mathrm{La}_{2} \mathrm{MgO}_{\mathrm{x}}(\#)$. 


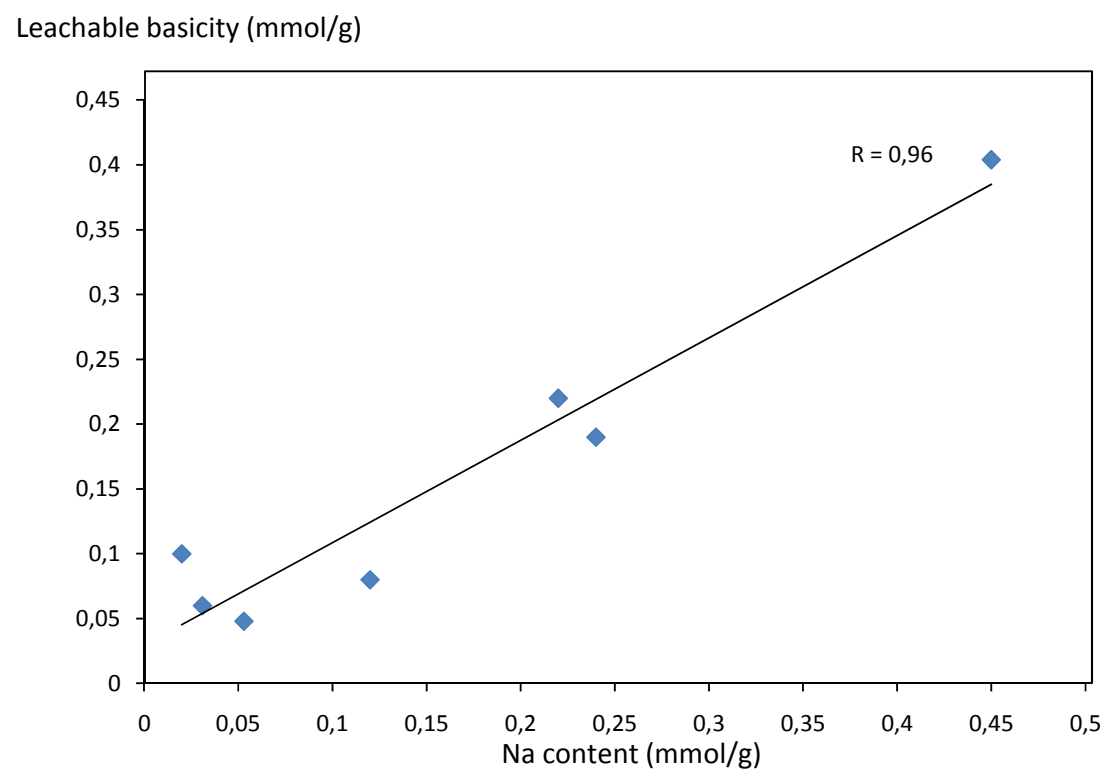

Figure 7. Representation of leachable basicity $v s \mathrm{Na}$ content for $\mathrm{Mg}_{9} \mathrm{M}(\mathrm{III})_{1}$ solids.

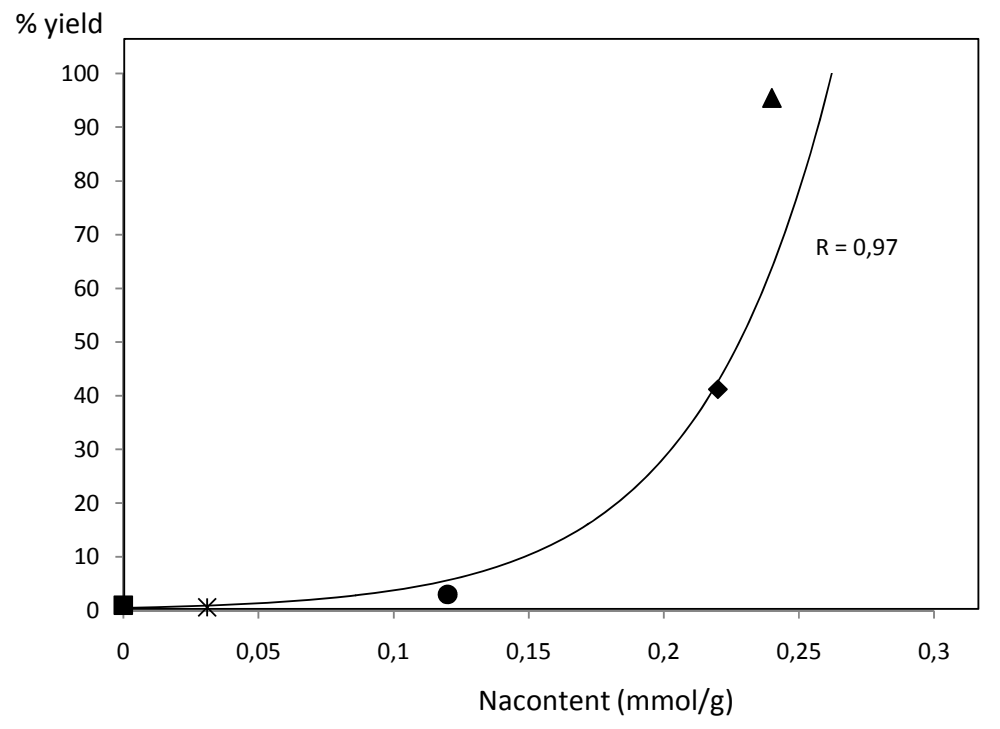

Figure 8. Representation of transesterification yields of methyl palmitate with isobutanol catalyzed by $\mathrm{Mg}_{9} \mathrm{M}(\mathrm{III})_{1}$ solids vs sodium content. ( $\left.\mathbf{\Delta}\right) \mathrm{Mg}_{9} \mathrm{Al}_{1}$, (४) $\mathrm{Mg}_{9} \mathrm{La}_{1}$, (•) $\mathrm{Mg}_{9} \mathrm{La}_{1}$ (thoroughly washed), (*) $\mathrm{Mg}_{9} \mathrm{Ga}_{1}$, (ロ) $\mathrm{Mg}_{9} \mathrm{La}_{1}\left(\mathrm{NH}_{4}\right)$. 